\title{
Quo vadis regionalizmus? Egy eszme- és értékrendszer tovább élése a szakemberek közvetítésével
}

\section{Quo vadis regionalism? \\ The subsistence of a conceptual and value system through the professionals}

\author{
JÓZSA VIKTÓRIA
}

JózSA Viktória: ügyvezető, Nord Consult Kft.; 1106 Budapest, Jászberényi út 45.; viktoria.jozsa@gmail.com; https://orcid.org/0000-0002-6897-080X

KULCSSZAVAK: regionalizmus; intézményrendszer; szakemberállomány; egyéni pályák; kohéziós politika; alapelvek

ABSZTRAKT: Hová tartasz, regionalizmus? A kérdés aktualitását a kutatás évében (2017) nemzetközi szinten a Római szerződés és az általa létrehozott Európai Szociális Alap 50. évfordulója adta, hazai viszonylatban pedig a területfejlesztésről és területrendezésrőll szóló törvény hatálybalépése óta eltelt mintegy 20 év. Mindeközben 2016-tól a regionális intézményrendszer szinte teljes mértékben megszűnt Magyarországon.

A kutatás célja a történtek feldolgozása, a regionális intézményrendszer kialakulása, tündöklése, majd bukása (?) során létrejött szakmai közösség továbbélésének segítése volt. A tanulmány alapjául szolgáló kérdőíves felmérést a korábbi Regionális Fejlesztési Ügynökségek (RFÜ-k) munkatársainak körében végeztem el. A kutatás vizsgálta, hogy az európai uniós eszme- és értékrendszer tovább él-e a szakemberek közvetítésével; a regionális (kohéziós) politika alapelvei - a koncentráció, a partnerség, az addicionalitás, a szubszidiaritás -, az elsajátított gondolkodásmód, a stratégiai programozási gyakorlat, logika beépültek-e a szakemberek gondolkodásába, alkalmazzák-e azokat jelenlegi munkahelyükön mindennapi gyakorlatukban. Egyáltalán, mi történt a megszünt vagy átalakult RFÜ-k munkatársaival?

A kutatás eredményei alapján elmondható, hogy az RFÜ-k korábbi személyi állománya magasan képzett, motivált szakemberekből állt, akiknek meghatározó része jelenleg is ugyanabban a régióban, de többféle szervezetnél tevékenykedik a területfejlesztésen belül. Az újbóli elhelyezkedés viszonylag zökkenőmentesen zajlott, ám a szakemberek továbbra is nosztalgiával gondolnak vissza az RFÜ-s munkavégzésre. Egyértelmű és erős igényük van a szakmai kapcsolatok ápolására. A tanulmány hidat képez múlt és jövő között. Ezáltal hozzájárulhat ahhoz, hogy ez a szakmai közösség újra tudja pozicionálni önmagát, és szakértelmével, tapasztalatával segíteni tudja hazánk felkészülését a 2020 utáni programozási időszakra.

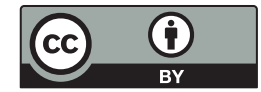


Viktória JÓZSA: CEO, Nord Consult Ltd.; Jászberényi út 45; H-1106 Budapest, Hungary; viktoria.jozsa@gmail.com; https://orcid.org/0000-0002-6897-080X

KEYWORDS: regionalism; institutional system; professionals; personal development paths; cohesion policy; key principles

ABSTRACT: Quo vadis regionalism? Two anniversaries in the year of this survey (2017) underline the relevance of this question: the 50th anniversary of the Treaty of Rome and the European Social Fund, at the international level, and the recent 20th anniversary of the Act XXI of 1996 on Regional Development and Regional Planning and the mid-term evaluation of the 2014-2020 programming period, in the national context. The previous year (2016), an earlier government decision almost totally abolished the institutional system on the regional level in Hungary.

This survey did not aim to mourn the past or to explore and justify the motivations behind the government decision. It focuses on the individuals and their contribution to the professional community they formed during the existence of the regional-level administrative system. The demise of the system was hoped not to disrupt the close-knit professional community and the personal contacts it engendered.

A questionnaire-based survey was conducted within the circle of professionals formerly employed or contracted by regional development agencies. The objective was to determine whether the professionals were able to keep alive the idea of regionalism and the conceptual and value system of the European Union. This encompassed the basic principles of EU regional (cohesion) policy such as concentration, partnership, additionality, subsidiarity, an acquired mindset, strategic programming practices and the corresponding conceptual framework. To what extent were these elements embedded in the thinking of the individuals surveyed and applied in their daily routines? What had actually happened with the former colleagues at the terminated or transformed regional development agencies (RDAs)?

For the most part, the former staff of RDAs are still working in the same region, but now as employees of a wide range of organisations in the field of regional development. Finding employment was relatively smooth but the professionals still have strong emotions and nostalgia towards their activities at the RDAs. They consider the RDAs more efficient, coordinated and more professional compared to their current employment and institutional framework. They exhibit a definite and strong desire to maintain professional links. This survey not only fills an information gap but also serves to bridge past and future. Thus, it contributes to the selfrepositioning of a middle-aged professional community that could significantly enhance the preparation of the post-2020 programming period and ensure an efficient and value-generating implementation of development programmes.

\section{Bevezetés}

Hazánk az 1990-es évektől kezdve éllovasa volt a területfejlesztési intézményrendszer kiépülésének a kelet-közép-európai térségben. Napjainkban azonban sokkal kevesebb kutatói érdeklődést kap a téma, aminek fó oka hazai szinten nyilvánvalóan a regionális intézményrendszer szinte teljes körü felszámolása, nemzetközi szinten pedig az a tény, hogy az Európai Unió kohéziós politikájában egyre inkább eltolódik a hangsúly a városok, városrégiók felé.

A jelenlegi helyzetben kiemelten fontos a szakma és a tudomány újrapozicionálása az egyének és az intézmények szintjén egyaránt, Rechnitzer (2017) megfogalmazásában „a nagy átértékelés korszaka következik”. Ezt azonban 
meg kell előznie a történtek társadalmi és egyéni szintű feldolgozásának és a tanulságok megállapításának. Ez nehéz és fájdalmas feladat, de a jövő érdekében az építkezésnek tiszta és erős, közösen felépített szerkezeti alapokról kell indulnia. Néhány év elteltével talán már van erőnk és lehetőségünk tisztábban látni a történéseket. Sok idő nincs erre, hiszen - ahogy az a kutatás eredményeiből egyértelműen kiderül - már napjainkban is égetően nagy szükség van a felhalmozott tapasztalatokra, kapcsolatrendszerekre, és ez az igény a következő - 2020 utáni - EU-s programozási időszak előkészítése és megvalósítása során csak növekedni fog.

Örvendetes módon van néhány olyan esemény, amely fórumot teremt a szakmai közösségépítésre, a találkozásra. Ezek közül némelyik évtizedes múltra tekint vissza, példaként említhetők a Magyar Regionális Tudományi Társaság (MRTT) Vándorgyülései, a Kistérségek Fejlesztéséért Tudományos Egyesület (KFTE) Területfejlesztők Víkendje rendezvényei, a konferenciák, mint például az MTA Regionális Tudományi Bizottságának (MTA RTB) Területpolitikai Albizottsága és az Eötvös Loránd Tudományegyetem Regionális Tudományi Tanszéke közös szakmai konferenciája 2016 végén (Józsa, Szabó 2017), vagy a 2017-ben először megrendezett nemzetközi Okos Közösségek Akadémia (Áldorfai et al. 2017). Fentiek mellett a hazai regionális tudomány jelentős ünnepe egy-egy tudományos műhely fennállásának kerek évfordulója (például a szegedi regionális tudományi műhely 20. évfordulója 2017 végén), az akadémiai tudományok doktora és az egyetemi doktori védések, más tudományos rendezvények (a Regionális Tudományi Esték, az Enyedi György Emlékkonferencia 2017-ben, vagy a Fiatal Regionalisták Konferenciája).

Fő motivációm a tanulmány megírására és az azt megelőző kutatás elvégzésére egyrészt a történtek társadalmi és egyéni feldolgozásának elősegítése, másrészt az elmúlt évtizedekben létrejött szakmai közösség egyben maradásának támogatása, harmadrészt pedig a téma iránti tudományos és szakmai érdeklődés felkeltése volt a további értékelések, következtetések, tanulságok levonása céljából. Végezetül tudományos szempontból is érdekes, hogy mi történt a régi kollégákkal, hogyan állják meg helyüket az új körülmények között az új munkahelyeken, hasznosul és tovább él-e az általuk megszerzett tudás, tapasztalat, kapcsolatrendszer, az RFÜ-s évek alatt megismert és alkalmazott eszme- és értékrendszer a mindennapok gyakorlatában.

\section{A hazai regionális fejlesztési ügynökségek}

Magyarországon a területfejlesztésről és a területrendezésről szóló 1996. évi XXI. törvény határozta meg a regionalizáció fö folyamatait, a törvény célja „a területfejlesztés és területrendezés alapvető feladatainak, szabályainak megállapítása, intézményrendszerének kialakítása" volt. ${ }^{1}$ 
A területfejlesztési törvény elfogadását, majd első módosítását (1999) követően megkezdődött a regionális intézményrendszer kiépítése, a döntéshozatali (tanácsi) és az operatív (ügynökségi) struktúrákkal (Józsa 2016). Ekkor alakult meg a tervezési-statisztikai régiókban a régiónként egy, azaz összesen hét regionális fejlesztési tanács (RFT) és a hét regionális fejlesztési ügynökség (RFÜ) is mint a tanácsok munkaszervezetei. ${ }^{2}$ Az RFÜ-k feladatai elsősorban hazánk Európai Unióhoz való csatlakozásának előkészítése, regionális szintű programozási feladatok ellátása és az előcsatlakozási alapok, azon belül is kiemelten a PHARE program regionális szintủ megvalósítása volt. A területfejlesztési törvény elfogadását követően a PHARE programoknak már nem a kistérségi és a megyei szint támogatása volt a célja, hanem a regionális szint megerősítése. A regionális szinthez elsőként az 1996-os PHARE program rendelt forrásokat (http://www.terport.hu 2005).

Magyarország Európai Unióhoz való csatlakozását követően az RFT-k és az RFÜ-k feladatköre kiszélesedett, többek között a regionális szintre decentralizált forrásokhoz kapcsolódó döntéselőkészítési, döntéshozatali, megvalósítási és monitoring funkciókkal. Elindult a 2004 és 2006 közötti „fél” programozási időszak, létrejöttek a megvalósításban közreműködő intézmények (részletesen lásd Józsa 2016).

2007-től összesen hét (régiónként egy) Regionális Operatív Program (ROP) megvalósítása indult meg. A ROP közremúködő szervezetek az RFÜ-kön belül működtek, az irányító hatóság 2006. július 1-jétől 2013. december 31-ig a Nemzeti Fejlesztési Ügynökség keretei között végezte feladatait. 2014-től a két területi operatív program, a Terület- és Településfejlesztési Operatív Program (TOP) és a Versenyképes Közép-Magyarország Operatív Program (VEKOP) irányító hatósága - új nevén Regionális Fejlesztési Programok Irányító Hatósága (RFP IH) - a Nemzetgazdasági Minisztérium keretén belül működött, egészen a közelmúltig.

Az RFÜ-k személyi állományát folyamatos növekedés jellemezte. A 2000-es évek elején, az alapítást követően néhány fős létszámról indulva a 2010-es évek elejére átlagosan 40-60 főre nőtt az egyes ügynökségeken dolgozó szakemberek száma.

A területfejlesztésről és területrendezésről szóló 1996. évi XXI. törvény módosításáról szóló 2013. évi CCXVI. törvény 12. §-a, valamint 18. §-a alapján azonban a nonprofit gazdasági társaság formában müködő Regionális Fejlesztési Ügynökségek 2014. január 1. napjával átkerültek a területileg érintett megyei (fóvárosi) önkormányzatok tulajdonába. A kormány a 397/2015. (XII. 12.) számú rendeletében (a 4/2011. (I. 28.) a 2007-2013-as programozási időszakban az Európai Regionális Fejlesztési Alapból, az Európai Szociális Alapból és a Kohéziós Alapból származó támogatások felhasználásának rendjéről szóló kormányrendelet 3. mellékletének módosításával) a Magyar Államkincstárat jelölte ki közreműködő szervezetként a Terület- és Településfejlesztési Operatív Program számára. Ezáltal az RFÜ-k sorsa megpecsételődött, mivel a közreműködő szer- 
vezet korábbi feladatai (a „hatósági funkció”) a forrásokkal egyetemben átkerültek a Magyar Államkincstár megyei igazgatóságaihoz. Az RFÜ-knél futó számos nemzetközi projektet pedig más szervezetek vették át. Az RFÜ-k megszűntek vagy átalakultak, számos esetben csoportos leépítés bejelentésével és végrehajtásával. A Pro Régió Ügynökség a Közép-Magyarország régióban folytatja korábbi tevékenységét.

\section{Rövid nemzetközi kitekintés és elméleti háttér}

A nemzetközi kitekintés során az Egyesült Királyság hazánkéhoz részben hasonlító esetét mutatom be. Az Egyesült Királyságban 1998 és 2010 között 9 regionális fejlesztési ügynökséget (Regional Development Agency, RDA) hoztak létre, elsősorban gazdaságfejlesztési célokra. Angliában minden NUTS 1 szintű régióban létrejött egy RFÜ, és a mintát Wales, Észak-Írország és Skócia is átvette. 2010 júniusában azonban az Egyesült Királyság kormánya bejelentette az RDA-k megszüntetését - ami 2012. március 31-én történt meg -, a költségvetési hiány csökkentésének szándékával.

A gazdaságfejlesztési tevékenységeket 39 helyi vállalkozási partnerség (Local Entreprise Partnership, LEP) vette át, amelyek Angliában a közös stratégiai keret finanszírozással foglalkozó intézményei 2014-2020 között (Morall 2013). A regionális fejlesztési ügynökségeket nem helyettesítették közvetlen módon a helyi vállalkozási partnerségek, mivel azok az első időkben nem kaptak állami támogatást és a helyi tanácsok sem kaptak decentralizált központi forrásokat. A rendszer ugyan müködik, ám mérleg készítése még korai.

A hazai szakirodalom gazdag a regionalizmus témájában, bár az elmúlt években - jelezve a szférában lezajlott radikális irányítási változásokat is - kevesebb írás született. A teljesség igénye nélkül hivatkozhatjuk a regionalizmus fogalmáról Süli-Zakar (2005), a hajtóerőkről Faragó (2004), a régiókról és a regionalizációról Illés (2001), a regionális politikáról és intézményrendszerről Döbrönte és Vida (2004), a regionális identitásról Somlyódyné Pfeil (2007), a regionális politikai és területi kormányzási ciklusok közép- és kelet-európai összehasonlításáról Pálné Kovács és Mezei (2016) műveit. Külön megemlítem Horváth (1998) tanulmányát az európai regionális fejlődés és politika távlatairól, aki optimistán tekintett a jövőbe a régióépítés intézményesítésének három szakaszával, valamint Nemes Nagy (1992) kevésbé optimista korai margójegyzeteit a regionális politikáról, amelyben kiemeli a térségi gazdaságfejlesztés jelentőségét a regionális politikán belül és a „nyugati másolhatatlan példák „majmolásának” kockázatait. A gyakorlat tartogatott meglepetéseket... Mint Pálné Kovács és Mezei írja (2016, 57.): „Mára egyértelmű, hogy a regionális decentralizáció a közép- és kelet-európai országok nagyobb részében csak rövid epizód volt." 


\section{A kutatás módszertana}

A kutatás során azt a meghatározást vettem alapul, amely szerint a regionalizmus föként a természeti, társadalmi, gazdasági törvényszerűségekre épülő területi kapcsolatok kialakulásának folyamata (horizontális integráció), amelyet a létrehozó tényezőkön és szervezeteken keresztül lehet megragadni (Lorenz 1991; Süli-Zakar 2005). A kutatás célja az volt, hogy a szakmai közösség szakembereinek sorsát bemutassam. A kutatást 2017-ben végeztem, kérdőíves lekérdezéssel, amelyet minden régióban egy-egy „régiófelelőssel” való személyes vagy telefonos kapcsolatfelvétel előzött meg. A régiófelelősök nagyban hozzájárultak az eltérő munkahelyeken dolgozó szakemberek eléréséhez és a kérdőív kitöltési arányának növeléséhez. Voltak olyan régiók, ahol a közösségi médiában csoport működik a volt RFÜ-s kollégák részvételével (például Észak-Alföld, Dél-Alföld, Közép-Magyarország), és voltak olyan régiók is, ahol csak személyes kapcsolatok maradtak fenn. A minta összeállítása során hólabdaelvet alkalmaztam, a régiófelelősöknek és az általam ismert szakembereknek közvetlenül megküldtem a kérdőívet, a régiófelelősök a közösségi média felületeire is feltették a kérdőív elérhetőségét és/vagy e-mailben megküldték azt a szakemberek részére. A Regionális Fejlesztési Ügynökségek személyi állományában valaha munkavállalóként dolgozó vagy megbízási szerződéssel, egyéni szerződéses jogviszonyban foglalkozatott szakemberek körébe nagyságrendileg 1000 fö tartozott. A kitöltés 2017. augusztus 15. és szeptember 30. közötti történt, 95 darab kitöltött kérdőív érkezett be, amelyek közül 92 volt minden kérdés kapcsán értékelhető. Ez 10\% körüli, a vizsgálat szempontjából elfogadható arányt jelent, mindemellett a felmérés nem tekinthető reprezentatívnak. A lekérdezéshez a minta sajátosságait figyelembe véve (fiatal- vagy középkorú, digitálisan írástudó, jól képzett, a számítógépet a mindennapi munkavégzés során aktívan és magas szinten alkalmazó szakemberek) Google-kérdőívet használtam és az anonimitás megőrzése érdekében a kérdőív kitöltésének nem volt feltétele a regisztráció. Ez nagyon fontos volt, mert már a kutatás megkezdésekor több olyan visszajelzés érkezett, miszerint a téma érzékenysége és a potenciális válaszadók jelenlegi munkahelye miatt kiemelt szerepe volt az anonimitás biztosításának. A legtöbb kérdésnél több válasz is megjelölhető volt. Fentiek tudatában kiemelkedő eredmény, hogy a kitöltők jó része megadta a kérdőív végén elektronikus elérhetőségét a további kapcsolattartás és a kutatás eredményeinek megküldése céljából.

A fó tematikus blokkok a kérdőívben az alábbiak voltak: szociodemográfiai jellemzők, az RFÜ-vel kapcsolatos tapasztalatok, a jelenlegi munkahely és tapasztalatok, a regionalizmussal kapcsolatos jövőkép és az ahhoz való viszony. A minta nemek szerinti megoszlása kiegyenlített volt (nők: 51\%, férfiak: 49\%), a kor szerinti megoszlásban több mint 65\%-ot képviselt az 1971-1980 között születettek aránya. Ehhez hozzáadva az 1981-1990 között születetteket (26\%), megállapítható, hogy a válaszadók meghatározó többsége az RFÜ-nél való elhelyezkedése és munkavégzése időszakában a 20-as és 30-as éveiben járó fiatal 
volt (akik ma már 10-15 évvel idősebbek). Az 1970 előtt születettek aránya 10\% alatti volt a mintában.

A válaszadók összetétele életvitelszerü lakóhelyük szerint tükrözi az egyes régiók eltérő válaszadási aktivitását. Kiemelendő, hogy minden régióból legalább 5 értékelhető kérdőív állt rendelkezésre. Nyugat-Dunántúlon és Dél-Alföldön (a visszaérkezett kérdőívek 59\%-ával) voltak a legaktívabbak a kollégák, és külföldről is érkezett két válasz.

Minden válaszadó felsőfokú végzettséggel rendelkezik és a teljes mintán belül magas (9,7\%-os) a tudományos fokozattal vagy MBA-végzettséggel is rendelkezők aránya. A szakterületek között a közgazdaságtani vagy területfejlesztési (azon belül regionális tudományi: 17\%) végzettséggel (is) rendelkezők aránya $85 \%$ feletti, ezt követik a mérnöki tudományok (17\%), az agrár- és a földrajztudomány $11 \%$-os és $9 \%$-os aránnyal. A jogtudományi (5\%) és szociológiai (3\%) végzettségüek aránya viszonylag alacsony.

\section{A kutatás eredményei}

\section{RFÜ-s tapasztalat}

Elsőként a válaszadók RFÜ-vel kapcsolatos tapasztalataira voltam kíváncsi, és arra, hogy melyik RFÜ-ben dolgoztak. A jelenlegi lakóhely és a korábbi, RFÜ-s munkavégzés helyszíne nem tér el jelentősen; a szakemberek többsége helyben talált munkát és helyben folytatja tevékenységét (71,4\% ugyanazon a településen és 6,6\% ugyanabban a megyében dolgozik, 9,9\% más megyében és 5,5\% más régióban dolgozik jelenleg). A válaszadók körében nem érvényesült jelentős munkaerőelszívó hatás, elvándorlás például külföld (2,2\%) vagy az ágazati minisztériumok (legfőképp Budapest, 6,6\%) irányába.

Az RFÜ-ben betöltött munkakört vizsgálva megállapítható, hogy főként a korábbi közreműködő szervezet munkatársai (61\%) voltak a válaszadók között. A tervezésben részt vevő válaszadók aránya 6\%, a kistérségfejlesztésben részt vevőké 13\%, a felső- és középvezetők aránya nagyjából 30\% volt. Ezek az adatok megfelelnek az RFÜ-nkénti és az országos átlagnak is, általában hasonló arányok voltak minden ügynökségnél. A mintában magas a nemzetközi projektmenedzserek aránya (30\%), ami egybecseng az RFÜ-kre jellemző jó nemzetközi kapcsolatokkal.

A válaszadók többségének (57\%) az RFÜ az első vagy a második munkahelye volt és a válaszadók meghatározó többsége (több, mint 82\%-a!) 5 évnél és csaknem egyharmaduk 10 évnél is többet dolgozott az RFÜ-nél (vö. 1. ábra). Mivel az RFÜ-k „életciklusa” átlagosan 15 év volt (az 1990-es évek második felétől a 2010-es évek közepéig), az adatokból kikövetkeztethető, hogy az RFÜ-s alkal- 
1. ábra: A válaszadók RFÜ-s munkaviszonyának időszakai Respondents' period of employment at RDAs

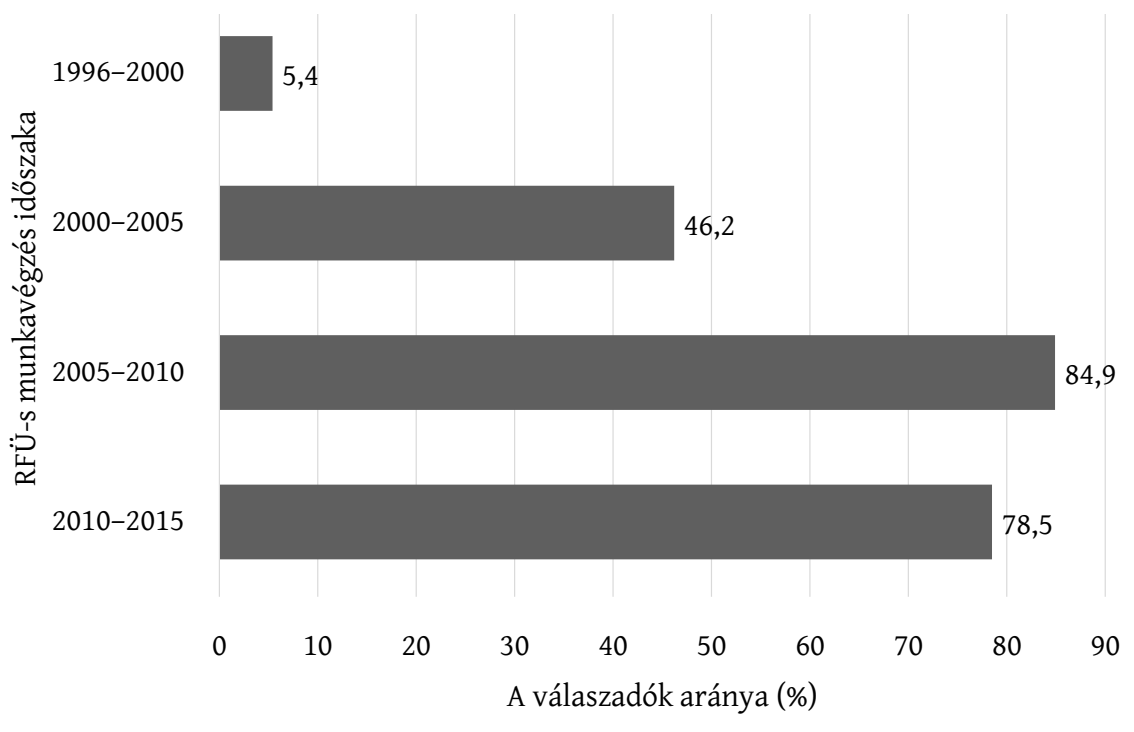

mazottak ragaszkodtak munkahelyükhöz. Az RFÜ-k személyi állománya stabil volt, amelyet az állományi létszám folyamatos felfutása jellemzett. Ez egészen 2015-ig tartott, amikor hirtelen változás következett be, amit nem előzött meg „lecsengés”, vagy tervezett, fokozatos leépítés.

Az RFÜ-től való távozás okaként a válaszadók 65\%-a az RFÜ-k megszüntetését, átalakítását jelölte meg, 4\%-uk a Nemzeti Fejlesztési Ügynökséghez vagy a Regionális Innovációs Ügynökséghez, esetleg projektszerződése lejárta miatt távozott. A válaszadók 17\%-a a jobb álláslehetőséget, 3\%-a a gyermekvállalást említette, további 6\%-a pedig negatív okokra hivatkozott (kiégés, a programtervezési feladatok beszűkülése, előremenekülés, a politika, az új vezetés vagy az összeegyeztethetetlen értékrend). Kiemelendö, hogy csak 1\% nevezte meg távozási okként saját tanácsadó cég alapítását.

Szerettem volna megfejteni, hogy ezeket a fiatal, jól képzett szakembereket mi vonzotta az RFÜ-khöz és a területfejlesztési pályára. Az elhelyezkedésnél a válaszadók fó motivációi az EU-hoz kapcsolódó érdekes feladatok (80\%), a folyamatos szakmai fejlődés és előrelépés lehetősége (58\%), valamint a döntéshozatalban, a régió fejlődésének elősegítésében való részvétel (57\%) voltak. Agilis, dinamikus, felelősen gondolkodó emberekről beszélünk tehát. A biztos, kiszámítható jövedelem (38\%) csak a negyedik helyen szerepelt az okok között. A stáb stabilnak volt mondható, alacsony fluktuációval, egészen a regionális intézményrendszer szinte teljes felszámolásáig. 


\section{„Mit az RFÜ adhatott..."}

A kérdőív következő részében arra kerestem a választ, hogy mit kaptak ezek a fiatal szakemberek az RFÜ-ktől, hogyan látják jelenleg egykori munkáltatójukat és használják-e a kapott vagy tanult ismereteket a mindennapokban, és ha igen, pontosan melyeket.

Az RFÜ-nél töltött évek értékelésénél 1-10 közötti skálán (1: nagyon rossz, 10: kiváló). a válaszadók több mint 92\%-a 8 és 10 közötti pontot adott. Kiemelendő, hogy a válaszok között nem volt 5 alatti érték, még a többi válasz kapcsán kritikusabb válaszadók esetében sem. Mint tudjuk, idővel minden megszépül, ám a további eredmények is ezt a pozitív hozzáállást támasztják alá.

Az RFÜ-nél töltött évek alatt a válaszadók elsősorban szakmai tapasztalatot és gyakorlatot szereztek a projekt- és programtervezésben, -megvalósításban és -monitoringban (96\%), kapcsolatrendszert építettek ki (89\%), megismerték az EU regionális (kohéziós) politikáját, alapelveit és értékrendjét (68\%), az RFÜ-s munkakultúra vonzotta a fiatalokat (61\%). Érkezett egy konkrét válasz is: a „perspektíva”.

A kutatás elvégzésével a cél nem a múlton való kesergés volt, sokkal inkább a történések dokumentálása és annak vizsgálata, hogy a regionális intézményrendszer képes volt-e új értéket, szemléletet, gondolkodásmódot és eszmerendszert közvetíteni dolgozóinak. A válasz egyértelmű igen. A kutatási eredmények azt támasztják alá, hogy az Európai Unió kohéziós politikájának alapelvei, eszme- és értékrendszere, gyakorlata tovább él a szakemberek közvetítésével. Az ezeket az ismereteket, tudást, kompetenciákat jelenleg is felhasználó szervezetek köre jelentősen kibővült, nem korlátozódik a területfejlesztési intézményrendszerre. A válaszadóknak az a véleménye, hogy a fontossági sorrend változott a konfliktuskezelési technikák, az ügyfelekkel való kommunikáció gyakorlata és a munkakultúra között, valamint megjelent egy új tényező: a nemzetközi szemlélet, gondolkodásmód és nyitottság hangsúlyozása (1. táblázat).

1. táblázat: A válaszadók által a jelenlegi munkahelyen alkalmazott, RFÜ-nél szerzett ismeretek Specification of the knowledge that the respondents apply at their current workplaces

\begin{tabular}{lc}
\hline \multicolumn{1}{c}{ A jelenlegi munkahelyen alkalmazott ismeretek } & Említési arány (\%) \\
\hline $\begin{array}{l}\text { Szakmai tapasztalat, gyakorlat } \\
\text { (projekt- vagy programtervezés, -megvalósítás, -monitoring) }\end{array}$ & 90,0 \\
Kapcsolatrendszer, szakmai és baráti ismeretségek & 72,2 \\
Az EU regionális politikájának ismerete (alapelvek és értékrend) & 51,1 \\
Konfliktuskezelési technikák, ügyfelekkel való kommunikáció gyakorlata & 50,0 \\
Munkakultúra & 46,7 \\
Elméleti és gyakorlati ismeretek a stratégiai programozásról & 34,4 \\
Képzések, tanulmányutak, egyéb tanulmányok & 13,3 \\
Nyelvismeret továbbfejlesztése & 13,3 \\
Nemzetközi szemlélet, gondolkodásmód, nyitottság & 1,1 \\
\hline
\end{tabular}


Megkérdeztem a válaszadóktól, hogy mi az első három szó, ami az RFÜ-ről eszükbe jut. Fontos kiemelni, hogy - egy-két, főként a kiábrándultságból fakadó negatív kifejezésen kívül - a használt szavak egyértelműen és erősen pozitív töltetűek voltak (2.ábra).

\section{2. ábra: A válaszadók eszébe jutó első három szó az RFÜ-kről} The first three mentions of respondents about the RDAs

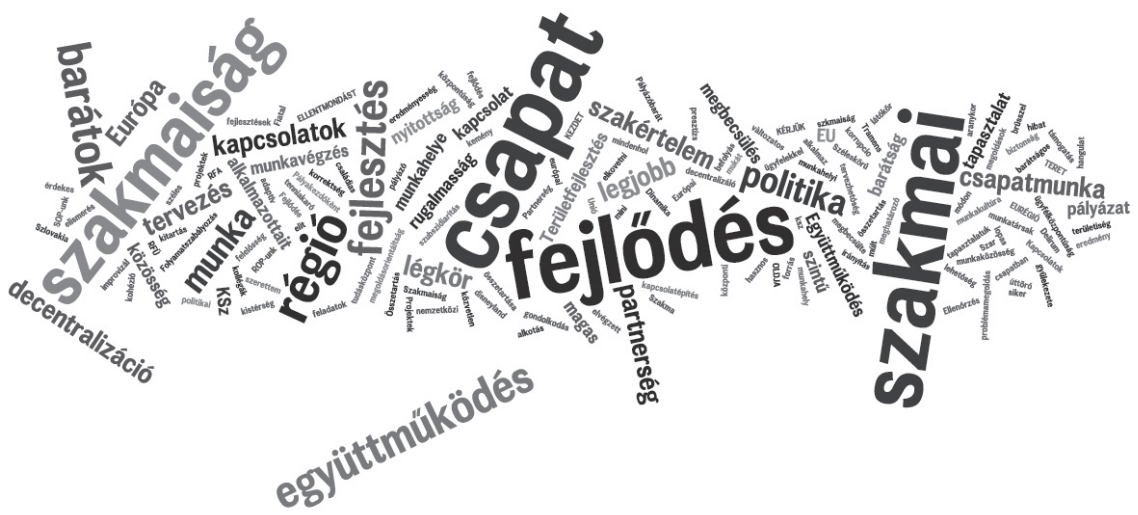

„Szervusztok, régi barátok”

Ebben a fejezetben azt mutatom be, hogy hol, milyen típusú szervezeteknél dolgoznak jelenleg a volt RFÜ-s szakemberek, mennyire volt jó gyakorlati alma mater az RFÜ, könnyű vagy nehéz volt-e az elhelyezkedés az új szervezetnél, és melyek a fö különbségek az RFÜ és a jelenlegi munkahely között.

A válaszadók nagyjából felét „felszívta” a tanácsadói szektor (24,7\%) és a területfejlesztési intézményrendszer megyei szintje (23,7\%). Ha ehhez hozzáadjuk a nemzeti $(11,8 \%)$ és regionális $(9,7 \%)$ szintủ szervezeteket és a helyi önkormányzatokat $(4,4 \%)$, akkor körülbelül a szakemberek háromnegyede továbbra is a területfejlesztésben tevékenykedik - vagy az intézményrendszeren belül, vagy a kedvezményezetti oldalon. Akik saját vállalkozásban folytatták tevékenységüket (14\%) vagy nagyvállalatnál helyezkedtek el (5,4\%), azok egyértelműen átkerültek a kedvezményezetti oldalra. A tanácsadást és a saját vállalkozást megjelölők között átfedés feltételezhető. Viszonylag jelentős $(10,8 \%)$ azok aránya, akik a felsőoktatásban, képzésben helyezkedtek el (amihez alapot jelentett a korábban megszerzett felsőfokú és az MBA-végzettség, a PhDfokozat) Feltételezhető, hogy a felsőoktatást megjelölők nem mind foállásúak és területfejlesztő tevékenységüket is folytatják. Az egyéb szervezeteknél foglalkoztatottak, a nyugdíjban, gyeden/gyesen lévők aránya együttesen $10 \%$ körüli. 
Érdekes adat, hogy bár többen (3,2\%) dolgoznak külföldön, ám egyikőjük sem az Európai Unió intézményrendszerében.

Az RFÜ-nél szerzett korszerü, versenyképes elméleti tudás, gyakorlat, kapcsolatrendszer, személyes ismeretség hatékonyan és gyorsan segítette az RFÜ-s kollégák későbbi elhelyezkedését. A válaszadók több mint fele $(52,2 \%)$ baráti kapcsolat és ajánlás útján helyezkedett el új munkahelyén. A válaszadók egynegyede $(24,4 \%)$ álláskeresés és -hirdetés, $11,1 \%$-a saját cégalapítás útján helyezkedett el. Míg a saját cég alapítását az RFÜ-től való távozás okaként mindössze a válaszadók 1\%-a nevezte meg, jelenleg több mint 10\%-uk saját, újonnan alapított cégben dolgozik; feltehetően egyfajta „kényszervállalkozóként”. Az RFÜ jogutódjánál vagy a korábbi anyaszervezetnél „egyenes ágon” elhelyezkedők aránya $7,5 \%$ volt. A válaszadók 70\%-a azonnal el tudott helyezkedni, 12,2\%-uk egy-két éven belül, és azóta is ugyanazon a munkahelyen dolgozik. További 7,8\% bár egy-két éven belül elhelyezkedett, azóta már munkahelyet váltott. A válaszadók között nem volt olyan, aki az „azóta sem helyezkedtem el foállásban" válaszlehetőséget jelölte meg.

A jelenlegi munkahely kapcsán is megkérdeztem, mi az első három szó, amely a válaszadó eszébe jut. A szófelhő (3. ábra) alapján csekély mértékű átfedés ugyan jelentkezik az RFÜ-s és a jelenlegi munkahely említéseiben (például csapat, fejlődés, pályázat, szakmai), ám a hangsúly főként a kihíváson, az önállóságon, a rugalmasságon, a felelősségen, a folyamatosságon, a biztonságon és függetlenségen van (amelyek kevésbé voltak az RFÜ-s és általánosságban a közigazgatási szektorban való munkavégzés sajátjai). Általánosságban megállapítható, hogy a szófelhő sokszínűbb, több a hangsúlyos kifejezés, de azok hangsúlya kevésbé erőteljes, mint a nagyon tiszta és erőteljes fókuszokkal rendelkező RFÜ-s szófelhőnél. Míg az RFÜ-k kapcsán az egyetlen negatívként értel-

3. ábra: A válaszadók eszébe jutó első három szó jelenlegi munkahelyükről The first three mentions of respondents about their current workplace

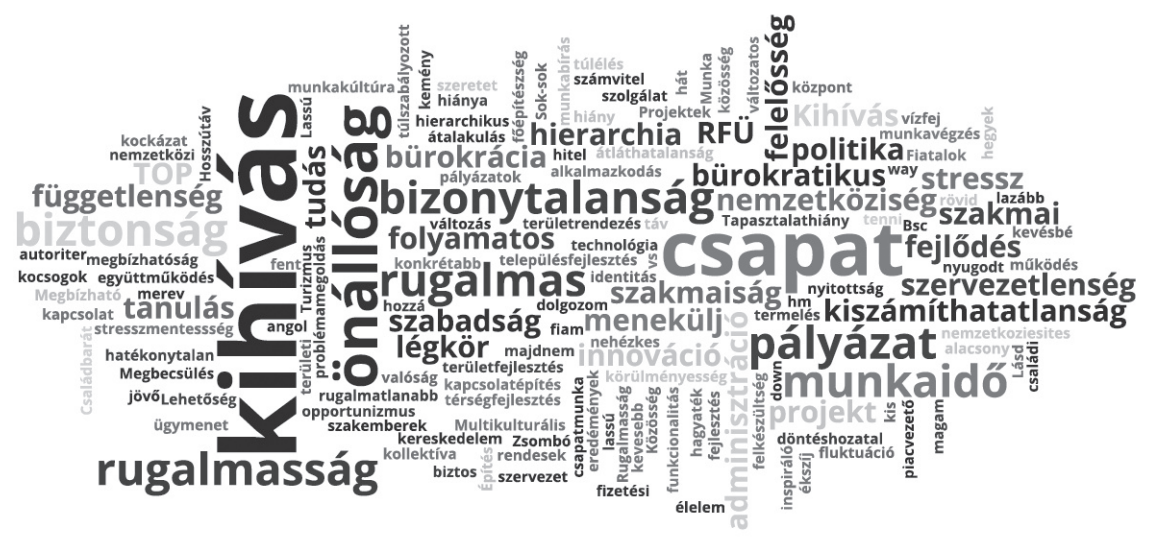


2. táblázat: Az RFÜ és a jelenlegi munkahely fö különbségei a válaszok alapján Main differences between RDAs and current workplaces, based on the responses

\begin{tabular}{|c|c|}
\hline Fö különbségek & Néhány jellemző válasz \\
\hline Keresleti vs. kínálati oldal & $\begin{array}{l}\text { Keresleti oldalon helyezkedik el, az RFÜ a fejlesztéspolitika kínálati } \\
\text { oldalán állt. } \\
\text { Az RFÜ-nél közremúködő szervezeti feladatokat végeztem, most } \\
\text { pályázatírással és megvalósítással foglalkozom. }\end{array}$ \\
\hline $\begin{array}{l}\text { Régi hatékony vs. új } \\
\text { erőforrás-pazarló rendszer, } \\
\text { az újrapozicionálódás } \\
\text { nehézségei }\end{array}$ & $\begin{array}{l}\text { Az RFÜ jól összeszokott, tapasztalt, önállóan dolgozni tudó, jó } \\
\text { szakemberek. Jelen szervezet „az új intézményrendszer”, sok } \\
\text { tapasztalatlan emberrel, sok stresszel, feszültséggel. } \\
\text { Az RFÜ-nél vezető voltam, újrakezdőként lent kezdtem, még közben } \\
\text { szerzett magas szintű szakmai képesítések mellett is. } \\
\text { Az RFÜ folyamatos kihívásokat, de stabil közeget, munkatársi } \\
\text { közösséget is adott. Mi voltunk az elit csapat. } \\
\text { A jelenlegi munkahelyen nem érzem azt, hogy maximálisan } \\
\text { hasznosítani tudnám a korábban szerzett tapasztalataimat, illetve } \\
\text { nem érzem annyira értelmét a munkámnak. }\end{array}$ \\
\hline $\begin{array}{l}\text { A piaci, vállalati közeg } \\
\text { sajátosságai, kiemelten a } \\
\text { nemzetközi közeg és a } \\
\text { méretkülönbségek }\end{array}$ & $\begin{array}{l}\text { Jelenleg egy multinacionális cégnél dolgozom a globális piacon, } \\
\text { szakmai vezetőként. Az abszolút nemzetközi környezet a } \\
\text { legjelentősebb különbség. } \\
\text { Pozitívum jelenlegi munkahelyemen, hogy politikamentes, más } \\
\text { jellegű vállalati politika érvényesül. } \\
\text { Most dolgozom elöször kkv-nál, az RFÜ után elég fájdalmas volt } \\
\text { találkozni a mai magyar vállalkozói lét valóságával... }\end{array}$ \\
\hline $\begin{array}{l}\text { Hozzáadott érték, a } \\
\text { munkahely minősége }\end{array}$ & $\begin{array}{l}\text { Az RFÜ-nél alakítója voltam a folyamatos fejlődésnek, itt még nem. } \\
\text { Kevesebb a munkateher, és nagyobb biztonságban érzem magam. } \\
\text { Itt számít a véleményem. } \\
\text { Az RFÜ szakmailag komolyabb kihívást jelentett. } \\
\text { Rugalmatlanság, a szakmai fejlődés hiánya, túlzott hierarchia, } \\
\text { érdektelenség. }\end{array}$ \\
\hline $\begin{array}{l}\text { Eltérő területi szint és } \\
\text { decentralizáció vs. } \\
\text { dekoncentráció }\end{array}$ & $\begin{array}{l}\text { Regionális szint helyett megyei szint. A központi koordináció } \\
\text { erőteljesebb megléte. } \\
\text { Városi lépték vs. regionális lépték } \\
\text { Vidéki nagyvárosi központ ↔ Budapesti központ. }\end{array}$ \\
\hline $\begin{array}{l}\text { Nagyobb szabadság, de } \\
\text { mellette nagyobb személyi } \\
\text { és anyagi felelősség }\end{array}$ & $\begin{array}{l}\text { A magam ura vagyok. } \\
\text { Kötetlen munkaidő távmunkában, otthonról. } \\
\text { Áttételesebb állami kötődés, kevésbé átpolitizált környezet, nagyobb } \\
\text { szabadság, kisebb biztonság. } \\
\text { Vállalkozóként magam vagyok a felelős a munka minőségéért, de a } \\
\text { feladatok megszerzéséért is. }\end{array}$ \\
\hline $\begin{array}{l}\text { Kiszélesedett } \\
\text { kompetenciaterület }\end{array}$ & $\begin{array}{l}\text { Több emberrel, több projekttel dolgozom egyszerre. } \\
\text { Kisebb szervezetben dolgozunk, több feladat van egy-egy emberen, } \\
\text { kisebb az itt dolgozók tapasztalata. }\end{array}$ \\
\hline
\end{tabular}


mezhető kifejezés a „politika” volt, a jelenlegi munkahely kapcsán számos, erőteljesen negatív kifejezés is megjelent, mint például a bizonytalanság, kiszámíthatatlanság, bürokratikus, stressz, hierarchia, menekülj, és (szintén) a politika. Érdekes továbbá, hogy az Európa és EU kifejezések helyett a nemzetköziség, nemzetköziesítés, nemzetközi és multikulturális szavak jelentek meg.

A jelenlegi és az RFÜ-s munkahely összehasonlításakor a válaszadók 39\%-a válaszolta, hogy nincs jelentős különbség a kettő között, 37\%-uk jobban szerette az RFÜ-s munkahelyét, és mindösszesen $15 \%$ válaszolta azt, hogy a jelenlegi munkahelyét jobbnak találja. A válaszadók maradék 9\%-a a „nem tudom megítélni” előre meghatározott, illetve a „nulla munka, két és félszeres fizetés”, a „jelenlegi munkahelyemen kevesebb a stressz, a feladat, de a fizetés is”, a „személyi állományt tekintve jobb, mint amire számítottam, de az RFÜ az ottani munkakultúra miatt jobb volt" szabadon megfogalmazott válaszokat adta. A 2. táblázatban a jelenleg különböző szervezeteknél dolgozók véleményeit is megjelenítettem.

\section{Saját jövőkép, viszony a regionalizmushoz, elégedettség}

A kérdőív utolsó blokkjában a volt RFÜ-s szakemberek jövőképére, a regionalizmushoz való viszonyára voltam kíváncsiak. A kérdéseket és az azokra adott válaszok megoszlását foglalja össze a 4. ábra.

Mivel a kérdések érzékeny területeket érintettek, így nem volt kötelező a megválaszolásuk. A teljes minta mintegy fele kapott egyfajta eszmeiséget, értékrendet az Ügynökségtől és szívesen visszamenne az Ügynökséghez, ha lenne rá módja. A válaszadók mintegy egyharmadát befolyásolták az Ügynökségen tanul-

4. ábra: A válaszadók kapcsolata a regionalizmussal a válaszok száma alapján

Relationship of the respondents with regionalism based on the responses

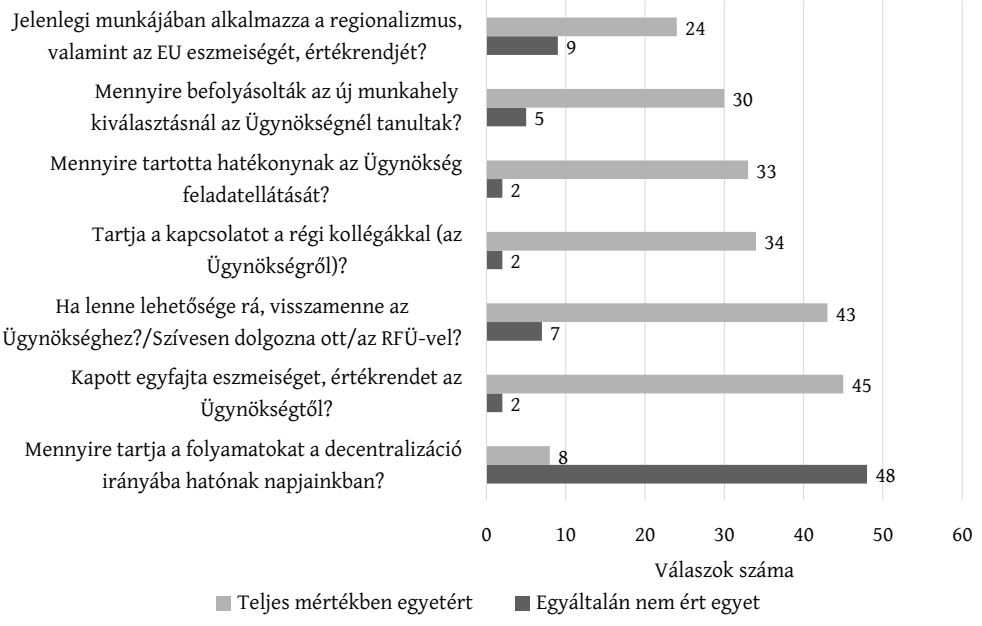


tak az új munkahely kiválasztásánál, és több mint egynegyedük jelenlegi munkahelyén is alkalmazza a regionalizmus, valamint az EU eszmeiségét, értékrendjét. Viszont a válaszadók több mint fele a jelenlegi folyamatokat nem tartja a decentralizáció irányába hatónak.

A regionalizmusról a válaszadók eszébe jutó első három szó közül a leggyakoribb kifejezések a decentralizáció, fejlesztés, együttműködés, helyi, RFÜ, partnerség, lehetőségek, EU, szubszidiaritás, a vidék és a terület voltak. Több hazai professzort név szerint is említettek, mint akiknek a neve összefonódott a regionalizmussal a gyakorlati szakemberek számára. A 3. táblázat a legjellemzőbb véleményeket foglalja össze.

3. táblázat: A regionalizmusról a válaszadók eszébe jutó első három szó First three mentions of respondents about regionalism

\begin{tabular}{|c|c|}
\hline Fö témakörök & Néhány jellemző válasz \\
\hline $\begin{array}{l}\text { Érzelmi töltetű } \\
\text { kifejezések }\end{array}$ & $\begin{array}{l}\text { decentralizáció, szubszidiaritás, múlt - fontos, volt, kivégezték... - szeretem, } \\
\text { múlt, remény - hiányzik - fejlődés, virágzás, rombolás, újrakezdés - volt, } \\
\text { eltűnt, nincs tovább - szunnyadó, valós, elengedhetetlen - a 2000-es években } \\
\text { azért dolgoztunk, hiába - RFÜ - Otthon, barátok, építés - régió, együtt, } \\
\text { egymásért - Meghalt, mindent a vízfejű Pest dönt el, térképen még jól néz ki } \\
\text { - NUTS } 2 \text { szint, fejlődési lehetőségek, szívügy }\end{array}$ \\
\hline Szakmai & $\begin{array}{l}\text { Európa, fejlődésbeli különbségek - Nyugat-Európa, rendszerváltás, EU- } \\
\text { integráció - decentralizáló, addicionalitás, közösségépítés - közösségek, } \\
\text { támogatások, együttműködés - programozott fejlesztés, lehetőségek - } \\
\text { elmélet a gyakorlattól távol - kapcsolat, politika, fejlesztés - kritikus tömeg, } \\
\text { stratégia, Európa - koordináció, szakmai támogatás, területfejlesztés - régió, } \\
\text { együttmüködés, globalizáció - decentralizáció, hatékonyság, partnerség - } \\
\text { tervszerűség, szervezettség, unió - RFÜ, VÁTI, stratégia - Európa, } \\
\text { modernitás, decentralizáció - térségi kohézió, határok nélküliség, } \\
\text { együttgondolkodás - régió, területi felosztottság, összefogás }\end{array}$ \\
\hline $\begin{array}{l}\text { Ki nem használt } \\
\text { lehetőség }\end{array}$ & $\begin{array}{l}\text { nem magyar sajátosság, ki nem használt lehetőség, újra szükséges definiálni } \\
\text { (Európa-szerte) - Van egyáltalán Magyarországon ilyen? - EU, itthon nem } \\
\text { működőképes, idea - szép idea volt - elmúlás, változás, politika - kísérlet, } \\
\text { lehetőség, bizonytalanság - EU, leszakadás, RFÜ - kihalóban van, átalakult az } \\
\text { intézményrendszer, jól működött }\end{array}$ \\
\hline $\begin{array}{l}\text { Decentralizáció, } \\
\text { politika }\end{array}$ & $\begin{array}{l}\text { helyben döntés, nem kormányzati érdekek - decentralizáció, saját döntések, } \\
\text { helyi érdekek - partnerség, kistérség, fejlesztés - szubszidiaritás, fejlett } \\
\text { európai térségek, fejlesztések - decentralizáció, regionális tanács, partnerség } \\
\text { - régiók, ügyfélbarát, tenni akarás - helyi érdekek, igények, jellemzők } \\
\text { figyelembevétele, lehatároltság - eszme, utópia, lokalitás - decentralizáció, } \\
\text { szubszidiaritás, együttmüködés - térségi szintű gondolkodás, NUTS, } \\
\text { együttgondolkodás - identitás, különbözőség, érdekképviselet - helyi } \\
\text { mozgástér, fejlesztés, lehetőségek - saját döntési hatáskör, együttműködés, } \\
\text { összefogáson alapuló fejlődés - hatékonyabb decentralizált feladatellátás - } \\
\text { decentralizáció, érdekérvényesítés helyi szinten, hatékonyság }\end{array}$ \\
\hline
\end{tabular}


A válaszadók 83\%-át érdekelné egy közösségi oldal, ahol kapcsolatba léphet azokkal, akik RFÜ-nél dolgoztak; 58 válaszadó az elektronikus elérhetőségét is megadta erre a célra. Végezetül pedig, a kutatást a válaszadók $84,3 \%$-a érdekesnek és hasznosnak tartotta, míg 4,5\%-uk szerint felesleges ezzel a témával foglalkozni. Egyéb válasz is kifejthető volt, az alábbi vélemények jelentek meg: „Örülök, hogy a véleményemet elmondhattam, de tudom, hogy semmit nem ér az már manapság. Ami elmúlt, elmúlt, előre kell tekinteni.” „Kellene egy szakmai együttműködési fórum (nem csak online).” „Érdekel a téma, viszont az RFÜ-k megszűnésével lehet, okafogyottá válik a kérdéskör.” „Érdekes, de felesleges, vissza nem jön. Nosztalgiázni jó, csak nem visz előre.” „Érdekesnek és hasznosnak találtam, de sajnos nem hiszem, hogy érdemi változásokat hozhat."

\section{Szubjektív összegzés}

Az írást sokadik nekifutásra sikerült véglegesítenem. A nyilatkozók véleménye, érzései minden alkalommal erőteljesen megjelentek a feldolgozás, összesítés során is. Volt, aki leírta, hogy azóta sem találja a helyét igazán, és hogy saját stratégiai gondolkodásának kibontakozása is az RFÜ-höz kötődik, sokkal kevesebb lenne a többéves RFÜ-s tapasztalat nélkül. Számos válaszadót foglalkoztat a kérdés, hogy vajon mi lesz a szerepe, helye a felhalmozott értékes tudásnak a 2020 utáni időszakban. A kutatás eredményeit látva a szakemberek meghatározó része számára továbbra is fontos a régióban, a területfejlesztési szakmában folytatni a tevékenykedést. Igaz, kicsit csalódottan és a múlt iránt érzett erős nosztalgiával, és nem is feltétlenül az új intézményrendszerben.

Ugyanakkor ez a tudás biztos alapot is képezhet a 2020 utáni EU-s programozási időszak tervezéséhez, a fejlesztések hatékony megvalósításához. Tovagyürűző hatása lehet a jól képzett, az EU „nyelvét”, módszertanát jól ismero szakembereknek a támogatáspolitika kínálati és keresleti oldali szervezeteinél. Ehhez azonban a szakmának, a szakembereknek a fejlesztéspolitika minden szintjén, a hatósági, a közvetítői és a kedvezményezetti oldalon össze kell fognia, hálózatosodnia kell. Lelkes, szívvel-lélekkel dolgozó fiatalból, sok esetben pályakezdőből a szakembereknek megfontolt, tapasztalt, érett, ám továbbra is motivált, együttműködő partnerekké kell válniuk. A hatékonyság növelése, a magasabb hozzáadott érték elérése, a szinergiák kihasználása és a közösségbe tartozás érzése motiváló. Számunkra, a volt RFÜ-sök számára segítette a történtek feldolgozását, a tanulságok levonását, a továbblépést ez a kutatási pillanatfelvétel. Reményeink szerint lesz ereje ennek a jól képzett, nemzetközi szinten is versenyképes szakmai közösségnek újrapozicionálni magát, egyben megtalálni, létrehozni és müködtetni a megfelelo", hatékony kommunikációs csatornákat a kapcsolattartásra, hiszen a kutatás eredményei alapján erre egyértelmű és erős igény mutatkozik. 


\section{Jegyzetek}

1 Ezt módosította az 1999. évi XCII. törvény, amely az ország Európai Unióhoz való csatlakozása előkészítése kapcsán szükségessé váló területfejlesztési intézményrendszer kialakítását, valamint a kormányzati struktúra átalakítását célozta. Újabb módosítással, a 2004. évi LXXV. törvény alapján megjelenik a kistérségi területfejlesztési tanács mint új szereplö. Ezt követően a 2011. évi CXCVIII. törvény rendelkezett a területfejlesztés intézmény- és eszközrendszerének jelentős átalakításáról, amely alapján 2012. január 1-jétől a megyei önkormányzatok tevékenységévé vált a területfejlesztési és a területrendezési feladatok ellátása. Végül pedig a 2013. évi CCXVI. törvény módosította az 1996. évi XXI. törvény több pontját.

2 A tervezési-statisztikai régiók (NUTS2) mellett az 1996. évi törvény a Balaton és a budapesti agglomeráció térségére is kijelölte feladatként térségi fejlesztési tanács létrehozását, így létrejött a Balaton Fejlesztési Tanács (BFT) és munkaszervezete, a Balatoni Integrációs és Fejlesztési Ügynökség Közhasznú Nonprofit Kft., valamint a Budapesti Agglomerációs Fejlesztési Tanács (BAFT) és munkaszervezete. A későbbiekben több térségi fejlesztési tanács is alakult (például Tisza-tó és Tokaj borvidék).

\section{Köszönetnyilvánítás}

Köszönöm szépen az együttműködést a volt (?) kollégáknak, akik megtiszteltek azzal, hogy véleményüket őszintén megosztották, még akkor is, ha az esetleg szomorú emlékeket ébresztett bennük. Köszönöm továbbá az együttműködést Szabó Pálnak, aki nemcsak a kérdőívet véleményezte előzetesen, hanem lehetőséget biztosított szekcióvezetőként a 2017. évi MRTT Vándorgyűlésen e kutatás eredményeinek bemutatására. Külön köszönet Nemes Nagy József és Rechnitzer János tanár uraknak, akik a kutatást már a gondolat megszületésétől támogatták. Végül köszönöm a lektorok alapos munkáját.

\section{Irodalom}

1996. évi XXI. törvény a területfejlesztésről és a területrendezésről Kihirdetve: 1996. IV. 05. http://net. jogtar.hu/jr/gen/hjegy_doc.cgi?docid=99600021.TV\#lbj7idf7ae (Letöltés: 2018. június 10.)

Áldorfai, Gy., Józsa, V., Káposzta, J., Nagy, H., Varga-Nagy, A. (2017): Challenges and development paths of Central and Eastern European locations in the globalised world - report on the first international smart communities academy. DETUROPE - The Central European Journal of Regional Development and Tourism, 3., 229-232.

Döbrönte K., Vida Sz. (2004): A regionális politika és intézményrendszer szerepe Magyarországon. Tér és Társadalom, 4., 1-28. https://doi.org/10.17649/TET.18.4.968

Faragó L. (2004): A regionalizmus hajtóerői Magyarországon. Térés Társadalom, 3., 1-23. 10.17649/TET.18.3.955

http://www.terport.hu/teruletfejlesztes/orszagos-szint/fejlesztesi-dokumentumok/2005 (Letöltés: 2018. június 10.)

Horváth Gy. (1998): Az európai regionális fejlődés és politika távlatai. Tér és Társadalom, 3., 1-26. https://doi.org/10.17649/TET.12.3.471

Illés I. (2001): Régiók és regionalizáció. Tér és Társadalom, 1., 1-23. https://doi.org/10.17649/TET.15.1.785

Józsa V. (2016): A magyarországi regionalizmus egy gyakorlati szakember szemével. Tér és Társadalom, 1., 37-55. http://doi.org/crtv 
Józsa V., Szabó P. (2017): Beszámoló és gondolatok a Térszerkezeti kihívások és területfejlesztési válaszlehetőségek a 2010-es években Magyarországon című konferenciáról. Tér és Társadalom, 2., 125-129. http://doi.org/crtx

Lorenz, D. (1991): Regionalisation versus regionalism - Problems of change in the world economy. Intereconomics, 1., 3-10. http://doi.org/dtgm8h

Morall D. (2013): Helyi partnerségek - kulcs az angliai támogatások folyósításához. Inforegio-Panorama, 45. http://epa.oszk.hu/01400/01414/00033/pdf/EPA01414_inforegio_panorama_45_26-30.pdf (Letöltés: 2018. január 11.)

Nemes Nagy J. (1992): Margójegyzetek a regionális politikához. Tér és Társadalom, 1-2., 69-79. https://doi.org/10.17649/TET.6.1-2.238

Pálné Kovács I., Mezei C. (2016): Regionális politikai és területi kormányzási ciklusok Közép- és Kelet-Európában. Tér és Társadalom, 4., 54-70. http://doi.org/crtw

Rechnitzer J. (2017): A regionális tudomány dualitása. Előadás, MRTT Vándorgyűlés, Mosonmagyaróvár, 2017. október 19-20.

Somlyódyné Pfeil E. (2007): Mozaikok a regionális identitás értelmezéséhez. Tér és Társadalom, 4., 57-71. https://doi.org/10.17649/TET.21.4.1139

Süli-Zakar I. (2005): Régió, regionalizmus és regionalizáció. TERD (The Impact of Tertiary Education on Regional Development) program. http://terd.unideb.hu/doc/konyv/1/b_suli_zakar.pdf (Letöltés: 2015. július 12.) 